\title{
KNOWLEDGE AND PRACTICE OF ENVIRONMENTAL SANITATION AND PERSONAL HYGIENE BY TRADERS. A CASE STUDY OF TAMALE CENTRAL MARKET
}

\author{
E. ARTHUR* AND A. Z. IMORO \\ (Department of Environment, Water and Waste Engineering, \\ School of Engineering, University for Development Studies). \\ *Corresponding author's email: arthurkernest@gmail.com
}

\begin{abstract}
Tamale is one of the rapidly growing cities in Ghana which is faced with numerous sanitation and hygiene problems. Markets generate large volumes of wastes due to their functions. Poor waste management in markets poses a threat to public health. This study sought to assess traders' knowledge and practice of environmental sanitation and personal hygiene. It also sought to identify the environmental sanitation challenges in the market. Questionnaire surveys, interviews, and personal observations were employed for data collection. The traders demonstrated fair knowledge on environmental sanitation but most did not practice recommended sanitation practices. Moreover, both males $(50.1 \%)$ and females $(49.9 \%)$ demonstrated good knowledge of personal hygiene and practiced it. The study identified poor drainage systems, lack of potable water, inadequate waste bins, littering, pilling of wastes, poor wastewater handling as major environmental challenges in the market. The findings of this study underline the need for bolstering up environmental education and hygiene promotion activities in public places like markets. It is also recommended that the toilet facility within the market get replace or renovated. The need for sanitation equipments and tools like wastebins should be met by the Metropolitan Assembly, as well as supports from NGOs and other bodies.
\end{abstract}

Keywords: Knowledge, practice, environmental sanitation, personal hygiene, traders.

\section{Introduction}

Worldwide statistics have accentuated the increasing rate of urbanization in developing countries. Africans' urban population is expected to increase by $54 \%$ by 2030 (UNPF, 2007), with cities' and towns' populations increasing by five million inhabitants each month (United Nations Human Resettlement Program, 2007). According to the World Health Organization (2006), this comes with a critical and unresolved challenge that affects the quality of life. It is assumed that the developing countries will follow the development path forged by industrialized countries (McGranahan \& Stockholm Environment Institute, 2001) and thus urban sanitary practices of the industrialized countries will influence those of developing countries. However, this is not the case.

Tamale is one of the fast-growing cities in Ghana considering its urbanization, infrastructure, and population growth (Human Development Report, 2010). This is accompanied by daunting problems in waste management, waterscarcity, and town planning. The management of solid and liquid wastes is a major environmental problems facing the Metropolis. According to an assessment by the 
United Nations Human Resettlement Program (2009), the metropolis generates about 150 tonnes of solid wastes and can only clear 7.5 tonnes daily. They added that $80 \%$ of the inhabitants depend on either community toilets or practice open defecation (United Nations Human Resettlement Program, 2009). They further indicated the need to procure sanitation facilities/ and equipment and the execution of existing sanitation plans and regulations.

The existence of markets in any city is expedient because commercial activities are the backbones of every country's economy. However, lack of control in the proliferation of markets and trading spells doom for cities due to inherent risks including; disease outbreaks, floods, and loss of aesthetic value (Fakere and Fadamiro, 2012). In the Tamale central market, the problem of environmental sanitation aggravates by the day. This includes poor waste management practices such as poor waste handling, and disposal methods, poor drainage systems, and inadequate sanitation equipment, and as well, reluctance in the enforcement of laws. Kankam-Yeboah et al. (2010) found that market places this country largely have poor sanitation condition. Traders in the market play a key role in the persistence of these problems. According to Worlanyo (2013), study in Dome Market, Accra, concluded that, most market users such as traders have no/less concern towards sanitation as a result of inadequate education on proper hygiene and sanitation. The study attributed their action towards sanitation to be attitudinal. The personal hygiene of traders is key to public health. According to Ofori et al. (2011), the environmental and hygienic situations at market centres in the country threatens public health including resident populations and market contributors. They expained that market places are potential sources of diseases, therefore there is the need for understanding the relationship between the systems of trading and the environmental condtions in a market. Thus, with no study on environmental sanitation and personal hygiene in Tamale Central Market, this study sought to ascertain and assess traders' knowledge and practice of environmental sanitation and personal hygiene to enable sound conclusions to be drawn on their contributions to the poor environmental state of the market.

\section{Experimental}

\section{Study Area}

Tamale, the capital of the Northern Region of Ghana is located within the Guinea Savannah belt with a land size of approximately 922 $\mathrm{km}^{2}$ (United Nations Human Resettlement Program, 2009). Its central market is geographically located within the GPS coordinates of $09.40591 \mathrm{~N}$ and $000.84263 \mathrm{~W}$. It is the most commercial hub within the region. The major facilities and amenities within the market area include; stores, smaller kiosks, vendors' platforms, unisexual urinary, toilet facilities, and a skip container. Most shops and stores are in clusters with small pathways. Trading activities take place in either well-built stores, kiosks or on tables, pans, and on the ground. The drainage system in the market is a shallow open-drain interchanging with a deep drain which goes around the market. Solid waste collection is based on the communal bin system. 


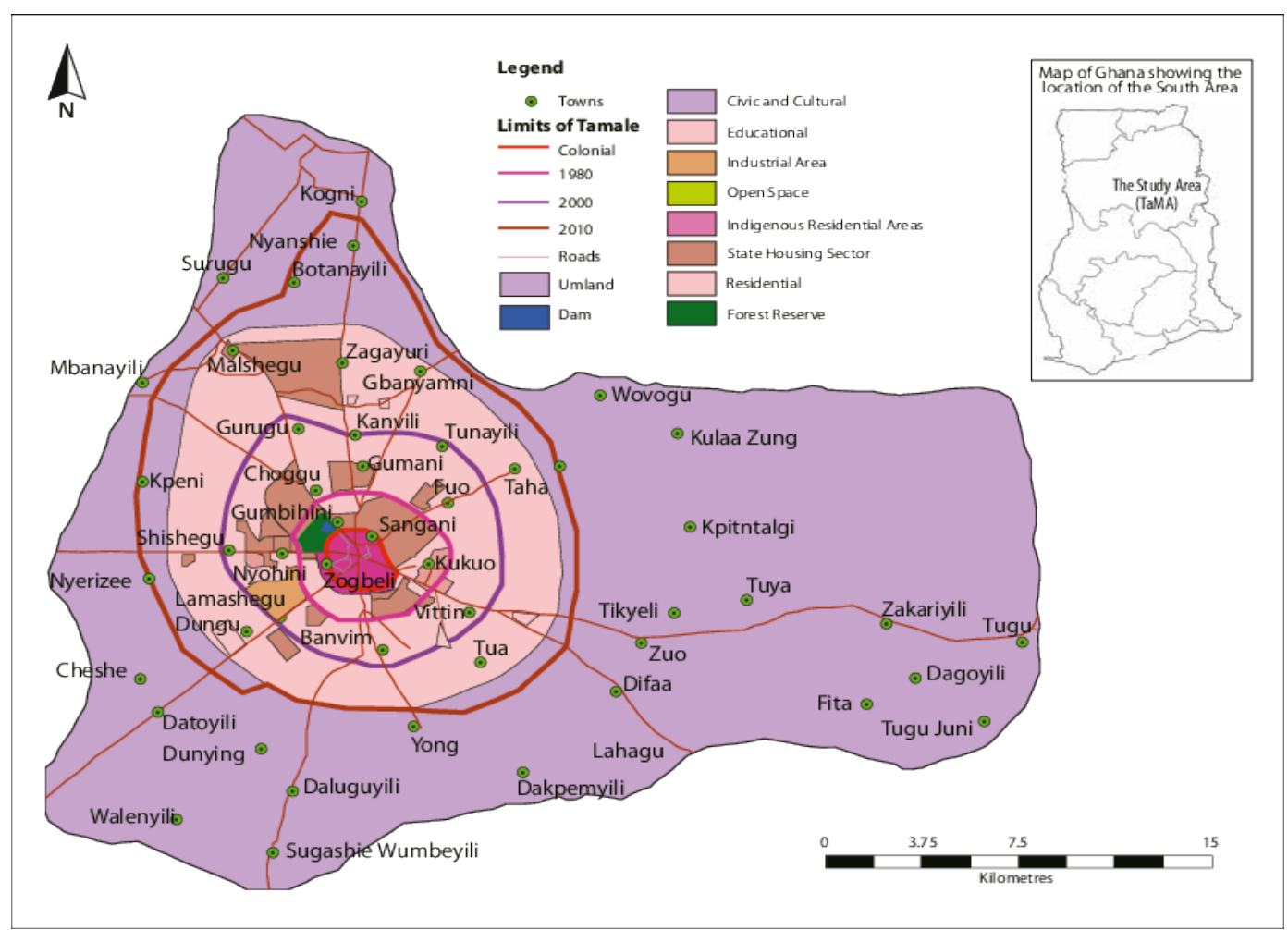

Fig. 1: Map of Study Area (Gyasi et al. (2014)

\section{Data collection}

Data was collected through questionnaire administration, interviews, and observations. The questionnaire used comprised of both opened and closed-ended question items. It was structured based on respondents' demographic characteristics, knowledge on environmental sanitation, practices towards sanitation, hygiene and hygienic practices. The instument was validated through construct validity: where environmental sanitation and hygiene indicators were considered. Convenient and purposive sampling methods were employed in the administering of the questionnaire. Convenient sampling made provision for participants who were readily available while purposive sampling was used for collecting information from key informants. Hundred
(100) respondents were engaged in the study. This sample size was arrived from Yamane's formula for estimating sample sizes (Agrasuta, 2013). Yamane formula: $n=\mathrm{N} /\left(1+\mathrm{Ne}^{2}\right)$, where $\mathrm{n}$ represent sample size, $\mathrm{N}$ represent population size and e represent the standard error $(0.05)$

The respondents comprised of store owners, foodstuff sellers, drug store operators, tailors, and seamstresses.

The duration of the study was four (4) months.

\section{Data analysis}

Data was analyzed through descriptive statistic tool in SPSS software (version 19) to obtain frequencies, percentages, as well as minimum 
and maximum values. Cross-tabulation and pearson chi-square was used to compare the relationship between variables. Microsoft Excel was used to present data in charts and tables.

\section{Results and discussion}

Demographic Characteristics of Respondents Results from this study showed that most of the respondents had received secondary education (39\%) whike the rest had basic education $(25 \%)$, tertiary education (18\%), and no formal education (18\%). Majority of the respondents were females $(57 \%$, Table 1$)$. Also, the youth (respondents below 40 years) dominated (83\%) this study (Table 1$)$.

\section{TABLE 1}

\begin{tabular}{lcc}
\multicolumn{3}{c}{ Demographics of respondents. } \\
\hline GENDER & Number & Percentages \\
\hline Male & 35 & 43 \\
Female & 45 & 57 \\
RELIGION & & \\
Christian & 13 & 16 \\
Islam & 67 & 84 \\
AGE & & \\
$20-40$ & 66 & 83 \\
$41-60$ & 14 & 17 \\
LEVEL OF EDUCATION & \\
Basic & 20 & 25 \\
Secondary & 31 & 39 \\
Tertiary & 14 & 18 \\
Total & 65 & 82 \\
Educated & 15 & 18 \\
\hline None & & \\
Educated & &
\end{tabular}

The majority of the traders being female (57\%) was expected and confirms Worlanyo (2013) findings that women make up about $51 \%$ of the labour force in Ghana. Meanwhile, the most economically active gender in Ghana is males (GSS, 2013). Also, the youth forming the majority (83\%) in this study confirms Ghana Statistical Service report that the country's population is young (below age 25 years) (GSS, 2013). The study finding more educated and a hand full of uneducated traders confirms the findings of the Ghana Statistical Service during the 2010 Population and Housing Census, that the economically active individuals in the region has increased and the number of national educated workforce increased from $10 \%$ in 1960 to $36 \%$ in 2010 .

\section{Educational level and trader's}

knowledge of sanitation and personal hygiene

As shown in Table 2, most (about 92\%) of the respondents irrespective of their educational level agreed that poor sanitation could cause diseases whiles the remaining $8 \%$ disagreed that poor sanitation cause diseases. Chi-square analysis showed that the respondents' level of education and their knowledge of "poor sanitation causing diseases" were not related $(p$-value $=0.097),($ Table 2$)$. Also, this study found that most $(87 \%)$ of the respondents, irrespective of their educational level identified solid waste as the common environmental pollutant in the market. Moreover, most (98\%) of the respondents, irrespective of their educational level agreed to the knowledge that, dropping waste into drains can cause flooding (Table 2).

All of those with secondary education (100\%), $94 \%$ basic education, $93 \%$ tertiary education, and with no formal education agreed that stagnant waters bread vectors of diseases (Table 2). On wastewater reuse, $77 \%$ of the respondents with secondary school education, $75 \%$ of those with basic education, and $60 \%$ of those with no education disagreed that wastewater can be reused (Table 2). 
It was found that most (65\%) of the respondents irrespective of their education agreed to the cleanliness of the market. Chi-square analysis showed that the respondents' level of education and their knowledge on the state of the market and "wastewater reused" were significantly related (p-value $\leq 0.05$, Table 2 ). It was interesting to find that the traders had general knowledge of environmental sanitation, including knowledge on identification of wastes; effects of poor sanitation, and effects of poor solid and liquid waste handling. This could be attributed to the formal education some had receive and sanitation related lessons learnt from religious institutions and cultural practices. This confirms the findings of Worlanyo (2013), that market users usually have a general knowledge about sanitation.

TABLE 2

Educational level and trader's knowledge on environmental sanitation.

\begin{tabular}{|c|c|c|c|c|c|c|c|}
\hline \multirow{2}{*}{$\begin{array}{l}\text { Indicators of } \\
\text { knowledge on } \\
\text { Sanitation }\end{array}$} & \multirow[b]{2}{*}{ Response } & \multicolumn{5}{|c|}{ Educational Level of Respondents } & \multirow[b]{2}{*}{$\begin{array}{l}\text { Average } \\
(\%)\end{array}$} \\
\hline & & $\begin{array}{l}\text { Basic } \\
(\%)\end{array}$ & Secondary $(\%)$ & Tertiary $(\%)$ & $\begin{array}{l}\text { None } \\
(\%)\end{array}$ & $\begin{array}{l}\text { Chi-Square } \\
\text { (p-value) }\end{array}$ & \\
\hline \multirow{2}{*}{$\begin{array}{l}\text { Poor Sanitation } \\
\text { can causes } \\
\text { diseases }\end{array}$} & Agree & 85 & 97 & 92 & 93 & \multirow[b]{2}{*}{0.097} & 91.8 \\
\hline & Disagree & 15 & 3 & 8 & 7 & & 8.2 \\
\hline \multirow{3}{*}{$\begin{array}{l}\text { Identification } \\
\text { of Common } \\
\text { pollutants }\end{array}$} & $\begin{array}{l}\text { Faecal } \\
\text { wastes }\end{array}$ & 10 & 10 & - & - & \multirow{3}{*}{0.128} & 5 \\
\hline & Solid waste & 90 & 87 & 79 & 93 & & 87.2 \\
\hline & $\begin{array}{l}\text { All of the } \\
\text { Above }\end{array}$ & - & 3 & 21 & 7 & & 7.8 \\
\hline \multirow{2}{*}{$\begin{array}{l}\text { Dropping of } \\
\text { wastes into } \\
\text { drains can causes } \\
\text { floods }\end{array}$} & Agree & 95 & 97 & 100 & 100 & \multirow{2}{*}{0.724} & 98 \\
\hline & Disagree & 5 & 3 & - & - & & 2 \\
\hline \multirow{2}{*}{$\begin{array}{l}\text { Stagnant water } \\
\text { breeds vectors }\end{array}$} & Agree & 100 & 94 & 93 & 100 & \multirow{2}{*}{0.487} & 96.8 \\
\hline & Disagree & - & 6 & 7 & - & & 3.2 \\
\hline \multirow{2}{*}{$\begin{array}{l}\text { Wastewater can } \\
\text { be reused }\end{array}$} & Agree & 25 & 23 & 64 & 40 & \multirow{2}{*}{0.036} & 38 \\
\hline & Disagree & 75 & 77 & 36 & 60 & & 62 \\
\hline \multirow{2}{*}{$\begin{array}{l}\text { This place is } \\
\text { clean enough as } \\
\text { a market should } \\
\text { be }\end{array}$} & Agree & 70 & 71 & 71 & 47 & \multirow[b]{2}{*}{0.365} & 64.8 \\
\hline & Disagree & 30 & 29 & 29 & 53 & & 25.2 \\
\hline
\end{tabular}

\section{Educational level and trader's knowledge of} hygiene.

It was also found that $90 \%$ of the respondents with basic education, $67 \%$ of those with no formal education, and $55 \%$ of those with secondary education disagreed that they had received education on hygiene. Chi-square analysis showed that the respondents' level of education and knowledge of hygiene was related ( $p$-value $=0.016$, Table 3). Asking on whether personal hygiene improved health, $90 \%$ of respondents with secondary education, $97 \%$ with basic education, $86 \%$ of those with tertiary education, and $93 \%$ of those with no 
formal education agreed that, good personal hygiene improved health. Moreover, enquiring about traders' knowledge of whether bathing promoted health, all the educated respondents $(100 \%)$ agreed to this whiles $7 \%$ of respondents without formal education disagreed (Table 3). Traders' response to the effect of cleanliness of clothes on health showed that all respondents with basic and tertiary education, $96 \%$ of those with secondary education, and $93 \%$ of those who had no formal education agreed that cleaned clothes promoted good health (Table 3).

All the respondents (100\%) agreed that clean nails promote good health. Also, $93 \%$ of respondents with basic education, all respondents with secondary education, and $93 \%$ of those with tertiary and no formal education agreed that regular hand washing promoted good health.

The respondents had good knowledge of hygiene with regards to hand hygiene, bathing, and clothes hygiene, irrespective of their educational level. It was understandable why most traders (65\%) claimed they never received training on hygiene but still expressed good knowledge and as well observed some recommended hygienic practices. Personal hygiene is learned involuntarily or voluntarily, either by observation, cultural practices, traditional obligations, or religious norms. Thurkill (2016) and Warsh, (2006) study stated that there is a large number of hygienerelated rules governing the lives of Muslims and Christianity. People get enlightened on personal hygiene through obedience to these kinds of religious rules. Also, personal hygiene is taught at the basic school levels thus it was expected that traders with secondary school levers and tertiary graduates who formed the greater part of the respondents' expressed good knowledge about it.

However, a study by the United Nations Human Settlement Programme (2009) on the Metropolis found that hygiene was poorly practiced by the inhabitants of Tamale. It can be said that the situation has improved base on this study's findings.

TABLE 3

Educational Level and Trader's Knowledge of Hygiene

\begin{tabular}{|c|c|c|c|c|c|c|}
\hline \multicolumn{2}{|c|}{ Indicators of Awareness of Personal Hygiene } & Basic $(\%)$ & Secondary $(\%)$ & Tertiary $(\%)$ & $\begin{array}{l}\text { None- } \\
\text { Educated (\%) }\end{array}$ & $\begin{array}{l}\text { Chi-Square } \\
\text { (p-value) }\end{array}$ \\
\hline \multirow{2}{*}{ Educated on Hygiene } & Agree & 10 & 45 & 57 & 33 & \multirow{2}{*}{0.016} \\
\hline & Disagree & 90 & 55 & 43 & 67 & \\
\hline \multirow{2}{*}{ Personal Hygiene improves Health } & Agree & 90 & 97 & 86 & 93 & \multirow{2}{*}{0.531} \\
\hline & Disagree & 10 & 3 & 14 & 7 & \\
\hline \multirow{2}{*}{ Bathing promotes health } & Agree & 100 & 100 & 100 & 93 & \multirow{2}{*}{0.222} \\
\hline & Disagree & - & - & - & 7 & \\
\hline \multirow{3}{*}{$\begin{array}{l}\text { Wearing clean clothes promotes } \\
\text { healthy life }\end{array}$} & Agree & 100 & 96 & 100 & 93 & \multirow{2}{*}{0.571} \\
\hline & Disagree & - & 4 & - & 7 & \\
\hline & Agree & 100 & 100 & 100 & 100 & \multirow{2}{*}{0.00} \\
\hline Clean nails prevent diseases & Disagree & - & - & - & - & \\
\hline \multirow{2}{*}{$\begin{array}{l}\text { Ensuring clean hands before eating } \\
\text { improves health }\end{array}$} & Agree & 93 & 100 & 93 & 93 & \multirow[t]{2}{*}{0.297} \\
\hline & Disagree & 7 & - & 7 & 7 & \\
\hline
\end{tabular}


Relationship between gender, religious affiliation, and waste disposal practice

As shown in Table 4, it was found that most males didn't dispose solid wastes into wastebins $(51 \%)$ as compared to those who dispose into the bins $(49 \%)$. The same appied to the females, having most of them (60\%) not disposing their solid waste into the waste-bins. Meanwhile, there were no significant difference between the number of males and the nuber of females who dispose solid waste into bins or do not dispose into bins ( $\mathrm{p}$-value $>0.05$ ). It was noticed that the situation was so because there were not enough waste-bins in the market. This confirms Amoah \& Kosoe (2014) findings that poor sanitation is motivated when there are no enough supply of waste containers as well as untimely clearance of waste by the sanitation agencies.

Also, the number of females who dispose their liquid wastes into drains were found to be more than (73\%) those who donot (27). The difference between the number of males and the number of females who discharge liquid waste into the drains and those who do not was also not significant ( $p$-value $>0.05$ ). Those who disposed of solid waste into waste bins were mostly Muslims (97\%) or Christians $(92 \%)$. Also, wastewater discharged into drains was practiced mostly by Muslims (71\%). A chi-squared analysis showed that the traders' religion and gender and their solid or liquid waste disposal methods were not related (p-value $\leq 0.05$, Table 4).

It was found that respondents' gender and religion had no influence on their waste disposal method. It was understood that respondent disposed their waste as it convenient to them. This is in consistent with the findings of Baffo (2015), who found that in seeking the convenient way to dump waste, traders irrespective of gender indiscriminately dump their solid wastes in drains.

\section{TABLE 4}

Gender, religious affiliation, and waste disposal methods.

\begin{tabular}{|c|c|c|c|c|c|c|c|}
\hline \multicolumn{2}{|c|}{ Demographic } & \multicolumn{3}{|c|}{ Solid Waste Disposal Method } & \multicolumn{3}{|c|}{ Liquid Waste Disposal Method } \\
\hline & & $\begin{array}{l}\text { Waste-bin } \\
(\%)\end{array}$ & $\begin{array}{l}\text { Not in waste- } \\
\text { bin }(\%)\end{array}$ & $\begin{array}{l}\text { Chi } \\
\text { Square } \\
\text { (p-value) }\end{array}$ & $\begin{array}{l}\text { Not in } \\
\text { Drains (\%) }\end{array}$ & $\begin{array}{l}\text { In Drains } \\
(\%)\end{array}$ & $\begin{array}{l}\text { Chi- } \\
\text { Square } \\
\text { (p-value) }\end{array}$ \\
\hline \multirow{3}{*}{ Gender } & Male & 49 & 51 & \multirow{2}{*}{0.347} & 50 & 50 & \multirow{2}{*}{0.334} \\
\hline & Female & 40 & 60 & & 27 & 73 & \\
\hline & Christian & 8 & 92 & \multirow[b]{2}{*}{0.705} & 66 & 34 & \multirow[b]{2}{*}{0.051} \\
\hline Religion & Muslim & 3 & 97 & & 29 & 71 & \\
\hline
\end{tabular}

Traders' satisfaction with the current environmental sanitation conditions Information received from the respondents as illustrated in Figure 1 showed that $41.25 \%$ of them were dissatisfied with the present environmental condition (drainage, sanitation, and waste management) $32.5 \%$ were indifferent, $23.75 \%$ were satisfied and $2.5 \%$ were very satisfied with the current environmental sanitation conditions. With close to half of the respondents (41.25\%) being dissatisfied was as a result based of factors 
like untiled ground which makes the market muddy during rainy seasons, poor drainage systems, bad state of toilet facility, lack of portable water and irregularity in collection of waste bin, hauls and piled wastes. A number of them (32.5\%) who could not express their satisfaction was found that, they had gotten used to the situation the market. This confirm the findings of Worlanyo (2013) that market users have an unchanged lifestyle towards the environment due to inadequate education. Those who felt satisfied thought that they need to embrace what they have available.

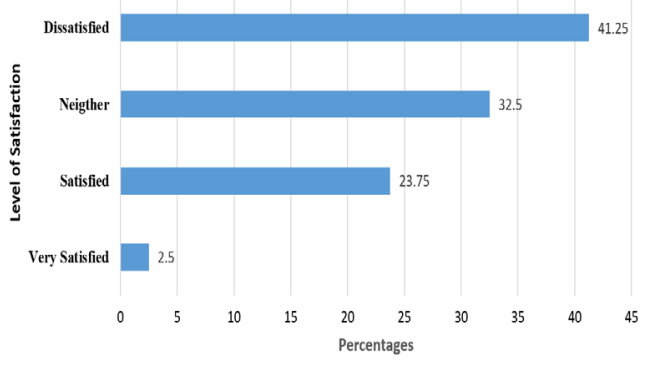

Fig: 1: Trader's satisfaction level about the market current environmental sanitation condition.

\section{Environmental sanitation practices}

This study also found that wastewater generated through day-to-day activities were discharged either into drains (71.3\%) or openly (28.7\%) (Table 5). The commonly generated solid waste was refuse and was discarded mostly by loading up in plastic bags $(49 \%)$, open ground( $7 \%$ ) and waste-bins (44\%). It was also found that $65 \%$ of the traders used the toilet facility in the market, $15 \%$ of them used their own toilet facilities, and $20 \%$ used toilet facilities outside the market (Table 5).

It was found that poor solid waste handling practices like inadequate waste-bins (only one bin ( 0.24 cubic metres)), reluctance on the part of traders to sweep their spaces, and the irregularity in the collection of waste by the Waste Collection Unit were the associated causes of the untidiness observed. The United Nations Resettlement Program (2009) reported that generally the waste management situation in the Tamale Metropolis is inadequate and characterized by the pile-up of garbage at collection points, littering in communities, inadequate disposal sites, and illegal disposal sites were common in Tamale. Thus the sanitation situation of the market could be a reflection of the earlier report.

Waste segregation was barely practiced. This was mainly as a result of insufficient knowledge with regards to the need for waste segregation and also inadequate waste-bins. According to Mamady 2016, poor knowledge by residents affects proper waste management practices.

The practice of wastewater disposal onto the ground was attributed to norms. Normally, in Ghana wastewater are discharged into surrounding bushes or open areas due to lack of drains in certain areas. It is an old practice that most people hardly forgo. According to Huuhtanen \& Laukkanen (2009), sanitation issues are mostly hard nut to crack due to strong prejudices, cultural matters, and beliefs. This notwithstanding, water and sanitation are essential in ensuring healthy living (WHO \& UNICEF, 2017).

Also, most traders preferred to use the toilet facility inside the market due to proximity, despite it bad state. The bad state of the toilet was attributed to the poor maintenance of the toilet facility by the operator. Due to this, black-water spillage was obvious, accompanied by a bad odour. The spillage mainly resulted from delays in the emptying of septic tanks. This confirms the findings of the United Nations Human Resettlement Program (2009) that Tamale Metropolis sanitation vehicles and equipment is a challenge. 
TABLE 5

Environmental sanitation practices of traders.

\begin{tabular}{lll}
\hline Related Practices & Responses & Percentages (\%) \\
\hline Waste Management & & \\
Disposal of & In the drain & 71.3 \\
liquid waste & On the ground & 28.7 \\
Solid waste disposal & Dispose on open ground & 7 \\
& Send into dustbin & 44 \\
& Keeps in plastic bags & 49 \\
Wastes Handling & No Segregation & 98.8 \\
& Segregate before disposal & 1.2 \\
Place of convenience & Public toilet inside the market & 65 \\
& Public toilet outside the market & 20 \\
& Private toilet & 15 \\
\hline
\end{tabular}

Hygiene practice and gender

This study showed that the percentage of females $(100 \%)$ who agreed to the practice of regular washing of hands was more than males $(97 \%)$ (Table 6). The percentage of males $(87 \%)$ who agreed to the practice regular bathing was more than females $(82 \%)$. Both genders practiced regular cleaning of fingernails. However, a chi-squared analysis showed that the traders' hygienic practice and gender was not related (Table 6). The study revealed that personal hygiene with regards to hand hygiene (washing with soap and clean fingernails) and regular bathing was practices by males $(50.1 \%)$ than female (49.9). This is in contrast with the report by Lusby et.al (2005), which revealed that more than half (54\%) of the global population maintained good personal hygiene, most being females $(59.5 \%)$ and the rest being males (44.5\%). 
TABLE 6

The practice of hygiene and gender.

Some Personal Hygienic practices Gender

\begin{tabular}{|c|c|c|c|c|}
\hline Preamble & Response & $\begin{array}{l}\text { Male } \\
(\%)\end{array}$ & $\begin{array}{l}\text { Female } \\
(\%)\end{array}$ & $\begin{array}{l}\text { Pearson Chi-Square } \\
\text { (p-value) }\end{array}$ \\
\hline \multirow[t]{2}{*}{$\begin{array}{l}\text { Regular washing } \\
\text { of hands with } \\
\text { soap }\end{array}$} & Agree & 97 & 100 & \multirow{2}{*}{0.254} \\
\hline & Disagree & 3 & 0 & \\
\hline \multirow{2}{*}{ Regular Bath } & Agree & 87 & 82 & \multirow{2}{*}{0.189} \\
\hline & Disagree & 13 & 18 & \\
\hline \multirow{2}{*}{ Clean fingernails } & Agree & 100 & 100 & \multirow{2}{*}{0.00} \\
\hline & Disagreed & 0 & 0 & \\
\hline Average (Agreed) & & 94.6 & 94 & \\
\hline
\end{tabular}

$\%$ of males/females who agreed $=$ average of agreed/total agreed. Males who agreed:94.6/188.6 $=50.1$ females who agreed $=49.9$.

\section{Major environmental challenges identified in} the study

The following were the main environmental challenges identified in the study area:

congestion of facilities, littering, inconsistency in cleaning, poor drainage system, odour from the toilet facility within the market, black-water from toilet facility, delays in wastes collection, reluctance in the enforcement of sanitation bye-laws and policies.

These challenges identified by the researcher is consistent with the findings of Baffo (2015) study in Tema New Town Market who found that the major challenges regarding poor sanitation in the market was indiscriminate dumping, lack of waste bins, drainage problem, inadequate sanitation facilities, attitudinal defect on the part of the traders towards sanitation, and lack of organisational supports.

\section{Conclusion}

This study found that traders in the Tamale central market had a fair knowledge of environmental sanitation and hygiene. However, It was understood that little to no enforcement of sanitation by-laws, inadequates sanitation equipments, inconsistency in cleaning and collection of waste by the waste management unit and poor attitude by traders are the major contributors to the poor environmental sanitation situation of the market. Their knowledge and practice of personal hygiene were quite commendable.

Challenges identified to be hindering the practice of good environmental sanitation in the market were, inadequate waste-bins, poor drainage system, congestion, and inadequate potable water. 


\section{Acknowledgements}

I thank God for his grace and support as I carried out this research. I also acknowledge my dear parents, Mr. and Mrs. Arthur for their warm support in throughout my studies. I also acknowledge Mr. and Mrs. Adjei-Mensah for their benevolence and warmness throughout my studies.

\section{References}

Agrasuta, V. (2013) The Adoption of Green Dentistry among Dentists in Thailand The Adoption of Green Dentistry among Dentists in Thailand. A dissertation submitted to the University of Manchester for the degree of MSc Healthcare Management, Manchester Business, pp.1 58 .

Аmoah, T. S. \& Kosoe, A. E. (2014) Solid waste management in urban areas of Ghana: Issues and experiences from Wa. Journal of Environment Pollution and Human Health, 2 (5), 1100117. Available at http://pubs.sciepub. $\mathrm{com} / \mathrm{jephh} / 2 / 5 / 3$.

Aryeetey, E. \& Nyanteng, V. (2006) Agricultural Market Access in Ghana. Discussion Paper No. 3 Institute of Statistical, Social and Economic Research. University of Ghana.

BAffoe, A. (2015). University of Ghana Department of Geography and Resource Development the Effect of Sanitation on Economic Activities: the Case of Tema New Town Market. UGspace. pp. $135-178$.

EzeKiel, C. (2013), National Sanitation Environmental Policy of Ghana; Strategic Youth Network for Development. Retrieved from mordernghana.com/news.

FAKere, A. A., \& FAdAmiro, J. A. (2012) Decentralization of Markets and Environmental Sanitation Scheme : A Focus on Urban Core of Akure, Nigeria. Journal of Environemtal and Earth Science 2 (8), $14-25$.
GHANA STATISTICAL SERVICE (2013) National Analytical Report: 2010 Population and Housing Census. Retrieved from Research Gate.

Gyasi, E. A., Fosu, M., Kranjac-Berisavljevic, G., Mensah, A. M., Obeng, F., Yiran, G.A.B. \& FuseINI, I. (2014) Building Urban Resilience: Assessing Urban and Peri-urban Agriculture in Tamale, Ghana. [Padgham, J. and J. Jabbour (eds.)]. United Nations Environment Programme (UNEP), Nairobi, Kenya, p. 50.

HUMAN DEVELOPMENT REPORT (2010) Resource Endowment, Investment Opportunities, and the Attainment of MDGs. Tamale, Ghana: UNDP.

Huuhtanen, S., \& LaukKanen, A. (2009) A guide to sanitation and hygiene in developing countries. Updated version 2. In Global Dry Toilet Association of Finland and Tampere University of Applied Sciences.

Luby, S. P., Agobatwalla, M., Feikin, D. R., Painter, J., Billhimmer, W., Atref, A. \& HoekSTAR, R. M. (2005) Effect of hand washing in child health. Lancet 366, $225-33$.

MAmady, K. (2016) Factors influencing attitude, safety behavior, and knowledge regarding household waste management in Guinea: A cross-sectional study. Journal of Environmental and Public Health 2016, 1-10.

MCGRANAHAN, G. \& STOCKHOLM ENVIRONMENT INSTITUTE (2001) The citizens at risk: from urban sanitation to sustainable cities. London: Earthscan.

Ofori, B. D., Ayivor, J. S. \& Agudogo-Yirenya, D. (2011) Institute for Environment and Sanitation Studies Environmental impacts of marketing and trading activities: Cause for concern. Retrieved from https://iess.ug.edu.gh/content/ ugiessib007-environmental-impacts-marketing-and-trading-activities-cause-concern. 
Thurlkill, M. (2016) Sacred Scents in Early Christianity and Islam: Studies in Body and Religion. Rowman \& Littlefield, 6-11.

UNITED NATIONS HUMAN RESETTLEMENT PROGRAM (2007) Framework for Global Water Operators Partnerships Alliance. Water, Waste Management \& Research, p. 24.

UNITED NATIONS HUMAN RESETTLEMENT PROGRAM (2009) Regional Technical Cooperation Division; Tamale City Profile, UN-HABITAT Regional and Information Offices Nairobi, Kenya, 4 - 29.

UNITED NATIONS POPULATION FUND (2007) The State of the World Population 2007: Unleashing the potential of urban growth. Indian Pediatrics 45 (6), 481 - 482.

Warsh, C. K. (2006) Children's Health Issues in Historical Perspective. Veronica Strong-Boag. Wilfrid Laurier Univ. Press. p. 315.
Worlanyo, E. K. (2013) Knowledge, Attitudes, and Practices of Sanitation, University of Ghana, Legon, 143.

WORLD HEALTH ORGANIZATION (2006) Children's Health and the Environment - A global perspective. A resource guide for the health sector. Geneva: Pronczuk J, Ed, p. 44.

WORLD HEALTH ORGANIZATION/UNITED NATIONS CHILDREN FUND (2010) Joint Monitoring Program. Progress on sanitation and drinking water. Geneva, p. 60.

WORLD HEALTH ORGANIZATION AND THE UNITED NATIONS CHILDREN'S FUND (2017) Progress on Drinking Water, Sanitation, and Hygiene: 2017 Update and SDG Baselines. Geneva, p. 66.

Received 01 Dec 20; revised 26 Jul 21. 